Helgoländer wiss. Meeresunters. 24, 401-414 (1973)

\title{
Lobster burrows in Swedish waters
}

\author{
B. I. DYBERN \\ Institute of Marine Research; Lysekil, Sweden
}

KURZFASSUNG: Hummerhöhlen in schwedischen Gewässern. Der europäische Hummer (Homarus vulgaris) wird vorzugsweise auf felsigen Böden mit Löchern und Spalten und felsigen oder sandigen Böden mit Steinblöcken und kleineren Steinen angetroffen. Vereinzelte Individuen sieht man auch auf ebenen Weichböden. Besonders tagsiber weilen die Tiere gern in Löchern bzw. Höhlen, welche die Hummer unter Steinen, Blöcken oder an Felswänden selbst ausgegraben haben. Viele Faktoren wirken bei der Wahl des Standortes zusammen, an dem eine solche Höhle ausgegraben werden soll. Unter Steinen und Felsen - vorzugsweise mit überhängenden Kanten - muß geeignetes Bodenmaterial vorhanden sein. Günstige hydrographische Verhältnisse sind eine weitere Voraussetzung. Fernerhin muß der Boden außerhalb der Höhle etwas schräggelagert sein; die Algenvegetation darf nicht zu dicht sein, damit die Sicht nicht eingeschränkt wird. Eine von einem anderen Hummer oder von einem Taschenkrebs verlassene Höhle nimmt der Hummer gerne in Besitz und verbessert sie, falls es notwendig ist. Verschmutzte Gewässer mit erheblicher Sedimentation und starker Trübung werden nicht besiedelt. Die meisten der gegrabenen Hummerhöhlen haben eine Offnung. Einige sind in der Art eines Tunnels gebaut, mit zwei - selten drei - Offnungen. Eine gewisse Relation zwischen der Größe einer Höhle und der des einwohnenden Hummers ist vorhanden. Oft aber bestimmt das Aussehen der unmittelbaren Umgebung die Größe der Höhle: so ist die Dimension eines oben liegenden Steines entscheidend für die Länge eines Tunnels. Auch in Lehmböden findet man ausnahmsweise gegrabene Höhlen. Die Art und Weise, in der der Hummer seine Höhle gräbt, wird kurz beschrieben. Die Arbeitsweise ist im Grunde stereotyp, sie wird aber zum Teil den speziellen Verhältnissen der Umgebung angepaßt. Kleine Hummer agieren in der gleichen Weise wie die adulten. Die Wahl des Aufenthaltsplatzes und das Ausgraben der Löcher ist dem Verhalten sehr ähnlich, das von Homarus americanus beschrieben worden ist. Die Art und Weise des Grabens erinnert auch an die von Nephrops norvegicus.

\section{DISTRIBUTION AND HABITAT OF THE EUROPEAN LOBSTER}

The European lobster Homarus vulgaris (L.) occurs down to about $40 \mathrm{~m}$ depth along the European west coast from the Tromsø area in northern Norway to the Aegean Sea (Havinga 1938 and others). In the Adriatic Sea it has been reported from the "zona littorale sommersa" and " $i$ fondi detrici" (VATova 1928). According to Alvarez (1946), it is found on Mediterranean rocky bottoms. Havinga (1938) describes it as living in hollows, but mentions also that it may be found on plain sand bottom with scattered stones and rocks. Off the coast of the Netherlands, the main habitat of the lobster is among the stones of the big embankments (Havinga 1951, Korringa 1957). From the British Isles, Thomas (1958) has recorded $H$. vulgaris on or near rocky 
bottoms. Simpson (1958) adds that it favours places where stones and rocks are found, but that it is found also on sandy bottom with stones, as off Yorkshire.

In Scandinavian waters the typical lobster habitat is rocky or sandy bottom with boulders and stones (Fig. 1) (Appellöf 1899, 1909, Stephensen 1910, Poulsen 1927, A. Dannevig 1936, G. Dannevig 1962, Höglund 1964 and Dybern et al. 1967). Most authors stress the importance of boulders and stones as hiding-places, and

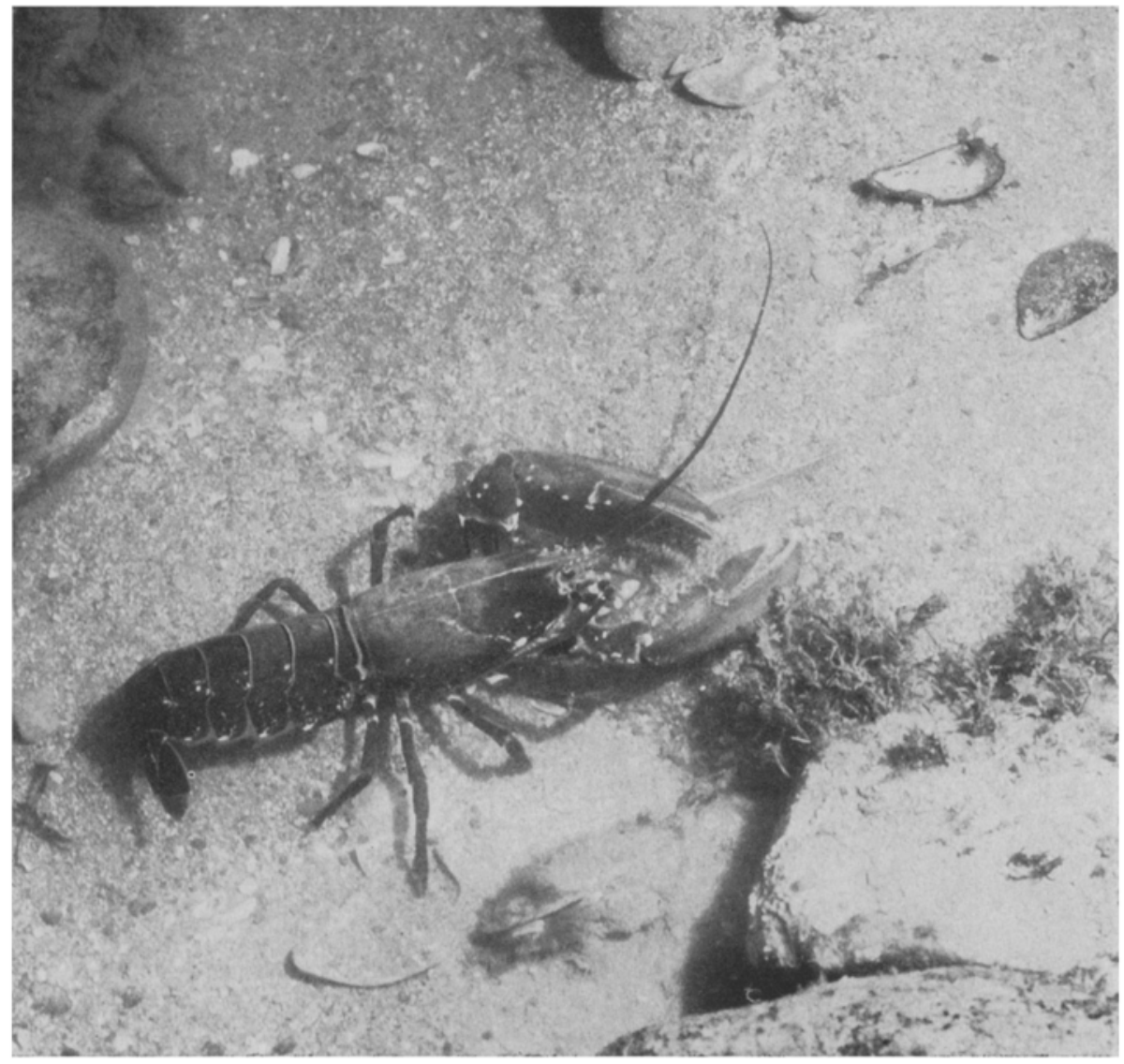

Fig. 1: Typical lobster bottom at about $15 \mathrm{~m}$ depth. (Photo: B. I. DyBern)

mention that the lobster can improve the shelters by digging burrows in sand under stones. Appellöf $(1899,1909)$ and A. DanNevig (1927) observed in breeding experiments that very small lobsters in this respect behave like the adults.

The American lobster Homarus americanus Milne EDwards, in populations living in near-shore areas, seems to occur and behave like the European lobster (e.g. Herrick 1895, Templeman 1937, Paloheimo 1963, Mcleese \& Wilder 1964, Scarratt 1968, CobB 1971). 
Both the European and the American lobster have occasionally been observed in flat, soft-bottom burrows also (Ehrenbaum 1896, Havinga 1938, McLeese \& Wilder 1964, ThOMAs 1968, CoBb 1971). Bö̈tius (1954) mentions briefly that burrows of adult lobsters in aquaria can be surrounded by a ring-formed wall.

\section{DISTRIBUTION AND HABITAT OF THE SWEDISH LOBSTER POPULATION}

On the Swedish west coast the European lobster occurs from the Norwegian border in the North to central Oresund in the South (Fig. 2). Most specimens are encountered at depths from $8-12$ to $30-40 \mathrm{~m}$. The southern and upper limits of distribution are mainly determined by salinity conditions.

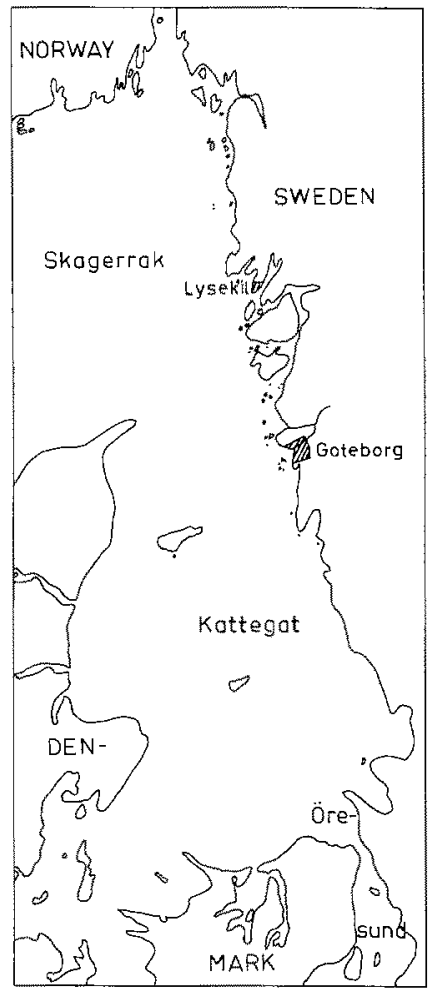

Fig. 2: Map of the Swedish west coast

An investigation on the habitat of the lobster, its burrows and behaviour, was started in 1964, mainly based on in situ studies which were completed with aquarium experiments. Some preliminary results of a detailed study of the lobster population in a small area off Lysekil were published some years ago (DYrERN et al. 1967). The 
present study on lobster burrows is based on the results of that and other studies along the whole west coast. The information given is based on daytime investigations made during the half-year from late spring to early autumn.

During the day, most of the lobsters dwell in their shelters; the main types of dwelling are listed in Table 1. The distribution of lobsters is, on the whole, uninterrupted along the coast, but the relative number of different places of habitat varies somewhat with the nature of the bottom. Most types of bottom can, however,

Table 1

Homarus vulgaris. Relative frequency of dwelling places of lobsters off the Swedish west coast (whole area of distribution). $0=$ very low, $5=$ very high. Based on studies of 260 individuals

\begin{tabular}{|c|c|c|}
\hline & Habitat or dwelling place & Relative frequency \\
\hline (A) & Rocky bottom & \\
\hline 1. & Unsheltered on the bottom & $0-1$ \\
\hline 2. & In hollows or crevices & $1-2$ \\
\hline 3. & Among and under boulders and stones on rocks & $2-3$ \\
\hline 4. & $\begin{array}{l}\text { In excavated hollows or crevices in rocks containing } \\
\text { soft-bottom material }\end{array}$ & $1-2$ \\
\hline (B) & Mixed bottom & \\
\hline 1. & Unsheltered on the bottom & 1 \\
\hline 2. & In natural hollows under boulders and stones, etc. & 4 \\
\hline 3. & In excavated burrows under boulders and stones, etc. & $4-5$ \\
\hline (C) & Soft bottom & \\
\hline 1. & Unsheltered on the bottom & $0-1$ \\
\hline 2. & In excavated burrows or tunnels & $0(-1)$ \\
\hline
\end{tabular}

be found over most of the coastline and the frequency figures listed in Table 1 give, presumably, an approximate over-all picture of the lobsters' preference for the different types of dwelling.

In the following, we shall mainly be concerned with type $\mathrm{B}: 3$, and some remarks will also be made on types $A: 4$ and $C: 2$; these are the three types of dwelling place where the lobster has actively improved upon natural conditions by using its burrowing ability.

\section{CHOICE OF SITES FOR BURROWS OF T'YPE B:3}

These burrows can be found either among dense agglomerations of boulders and stones where there are patches of soft-bottom material between stones, or under solitary boulders and stones lying more or less isolated on the soft-bottom (Fig. 3). Burrows may also be found at the base of solid rocks.

The soft-bottom material is most often shellsand, pure sand or a mixture of both. The shellsand can be rather coarse (Fig. 4). Less often the material is gravel or mud.

Preferably, the stone, boulder or rock should have originally overhung the softbottom material. somewhat and without penetrating deeply into this (Figs 3-4). The choice of such sites is confirmed in aquarium experiments. 
Sites where the bottom slopes outwards-downwards are also preferred. This means that on an evenly sloping bottom a great many burrows face the same main direction (exceptions may be due to local conditions, such as failure of overhanging stone parts, too dense algal vegetation, etc.). Compass direction seems to play no great role.

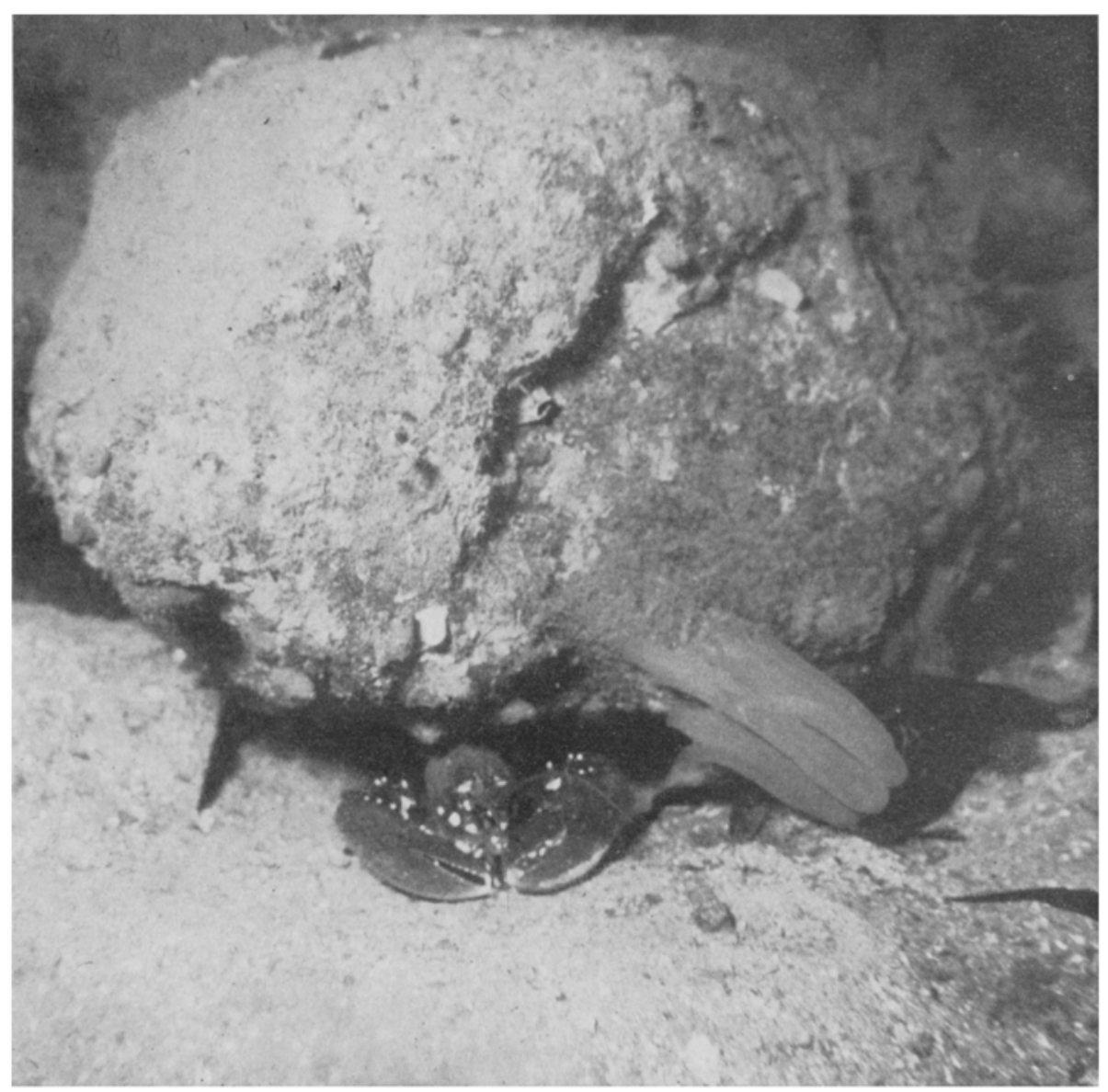

Fig. 3: Front opening of a lobster burrow under stone on a sloping bottom. This burrow also has a rear opening. Depth about $20 \mathrm{~m}$. (Photo: D. Ostrerlund)

The sea water on the Swedish west coast is vertically stratified. Figure $5 \mathrm{~A}$ shows typical summer conditions (July) for salinity and temperature on the central Skagerrak coast, and Figure $5 \mathrm{~B}$ the same parameters on the southern Kattegat coast (compare Fig. 2). The halocline is thinner in the latter area and the mean temperature below it lower than in the Skagerrak area. Above the halocline, salinity can fluctuate greatly and rapidly, especially in the Kattegat. The arrows in the diagrams indicate the main depth distribution of the lobster burrows. In the Skagerrak area, the 
burrows are common in the halocline but many can be found also above and below. In the southern Kattegat most of the burrows are found in or close beneath the thinner balocline. The explanation, it seems, for this behaviour is that the lobster chooses an environment with both the highest salinity and highest temperature possible simultaneously. As a compromise, most burrows will thus be situated in or close to

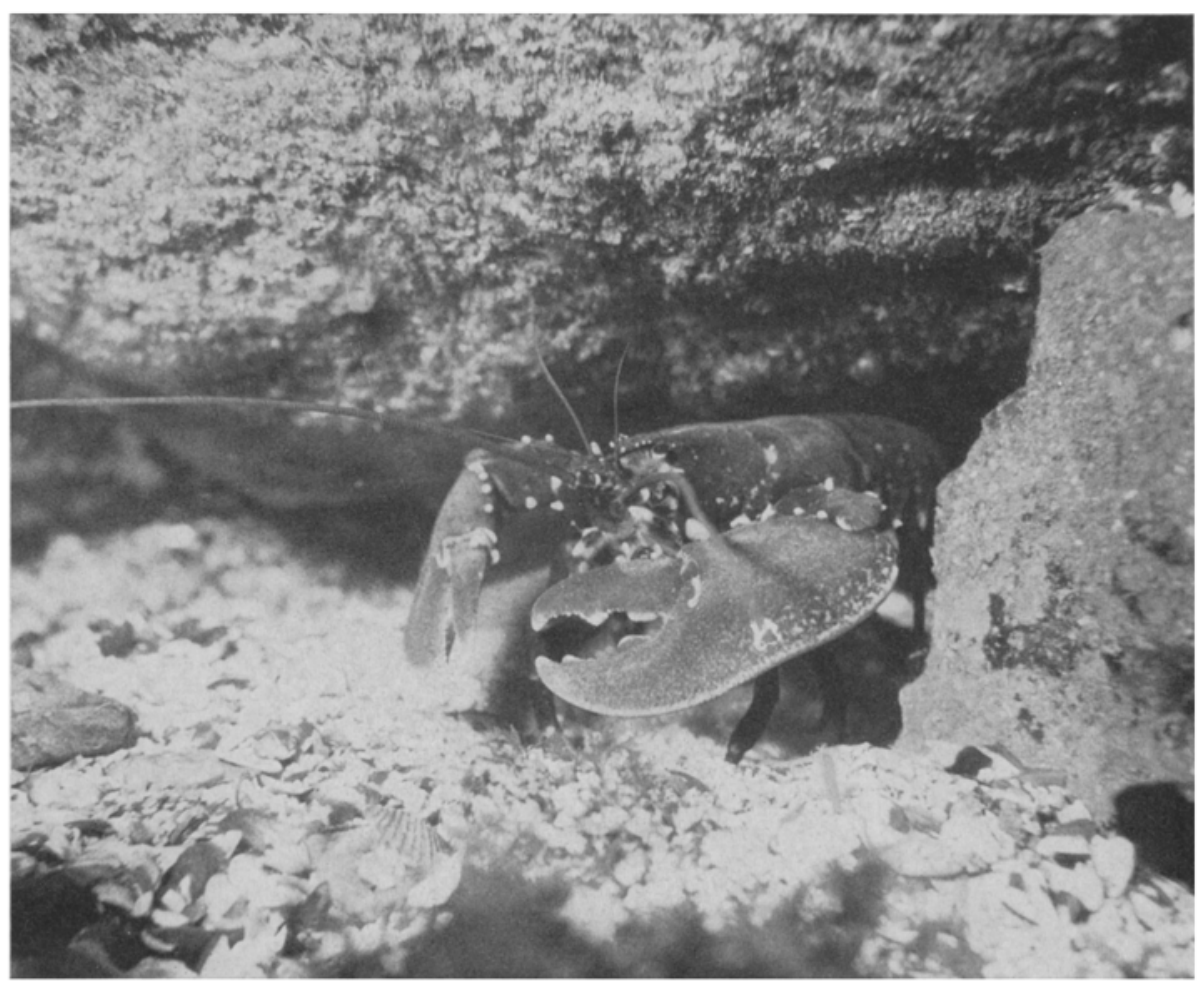

Fig. 4: Wall of coarse shellsand in front of a lobster burrow with one opening. Depth about $15 \mathrm{~m}$. (Photo: H. Carlsson)

the halocline. Where this is extended, the depth distribution will be wider. However, during nocturnal foraging, lobsters, especially in the Skagerrak area, can be found in very shallow waters, too; most likely this occurs when the salinity of the surface layers temporarily rises.

Most burrows are found at depths where the algal vegetation is less dense than in the surface layers. It seems the lobster avoids digging a burrow where algae may conceal the presumptive opening excessively, even if the site is suitable in other respects. As mentioned above, many burrows also face downwards in a sloping bottom. These facts indicate that burrows are used not only as hiding-places but also as look-outs (DyBERn et al. 1967). This theory is supported by the general habit of the lobster to lie half-way out of its burrow (Figs 3, $7 \mathrm{~A}, 8$ ). 
Lobsters tend to be absent from the polluted areas of coastal waters where the sedimentation rate of organic particles is high, even if other parameters are suitable. Unfavourable bottom-material composition in combination with high water turbidity seems to be the reason.
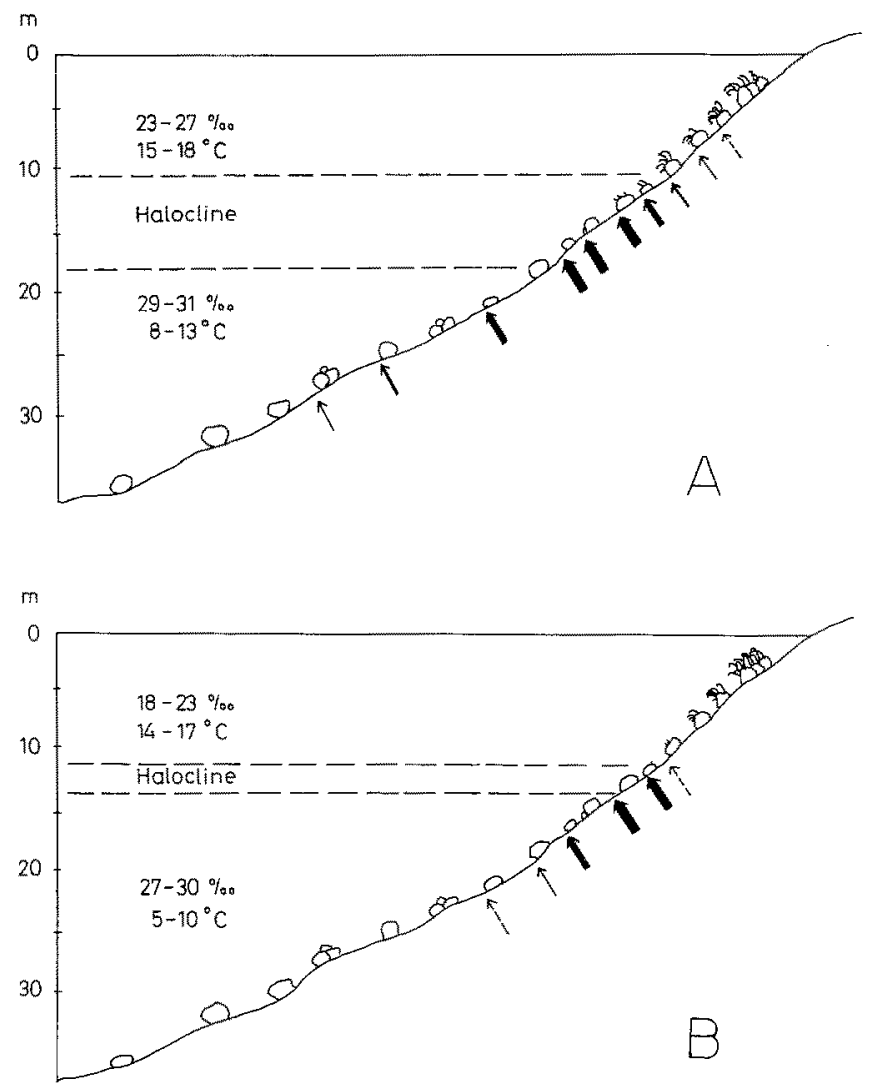

Fig. 5: Mean salinity and temperature conditions, and extension of halocline. A Central Skagerrak coast; $B$ southern Kattegat coast. Arrows indicate frequency of lobster burrows

\section{TYPES OF BURROW}

Burrows excavated under boulders and stones, or at the base of a rock, are of two main types: (1) Burrows with one opening. (2) Burrows with more than one opening, usually two.

Figure $6 \mathrm{~A}$ shows a longitudinal section of a typical burrow with one opening. In front of the entrance is generally a wall of excavated bottom material. Such walls are most conspicuous in front of recently excavated burrows, and they tend to be levelled off after the lobsters have finished digging and begun to move in and out. The bottom configuration determines the shape of the wall but where enough space is 
available it is more or less semi-circular (Fig. 6 B). The lobster typically rests against the inner side of the wall with its antennae directed forward as sensors (Fig. 7 A).

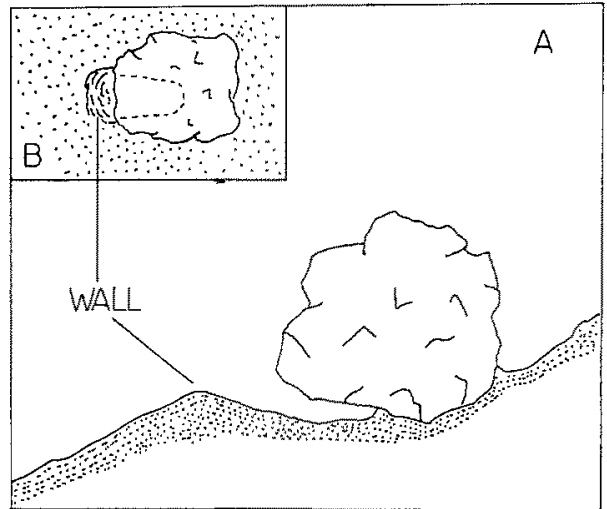

Fig. 6: Lobster burrow with one opening. $A$ longitudinal section; $B$ burrow seen from above

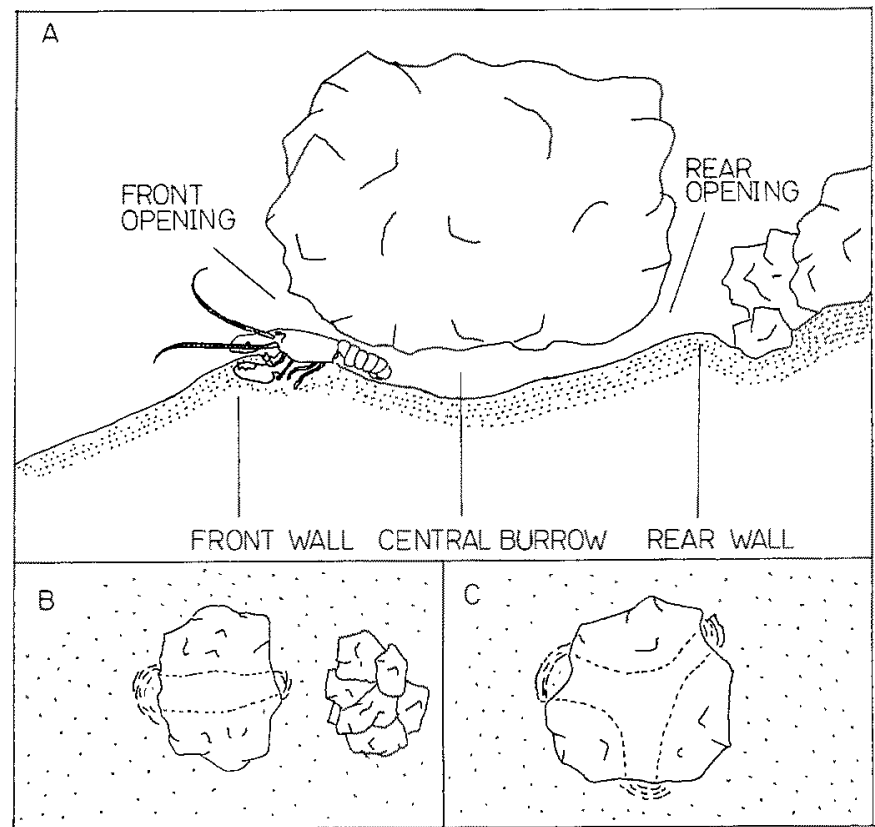

Fig. 7: Lobster burrows. $A$ Longitudinal section in form of a tunnel; $B$ burrow seen from above. $C$ Burrow with three openings

As a rule, the entrance of a typical burrow is just high enough to permit the lobster to rise on its legs and take up its defensive position (Fig. 4). The width of the opening is generally slightly greater than the height. The inside of the burrow is often enlarged into a kind of chamber. 
Совв (1971) who investigated similar burrows excavated by the American lobster, noted a relationship between the lobster's size and the size of its burrow and burrow-opening. In the present investigation, an approximate correlation between a lobster and its burrow has been found, too; but it was not possible to establish definite linear relationship because original configuration of a chosen site determines the burrow size (Fig. 3), and because lobsters often take over empty burrows excavated by other specimens, or by crabs (Cancer pagurus) which construct similar burrows. Very small lobsters tend to dig proportionately larger burrows, at least in aquarium tanks.

Figure $7 \mathrm{~A}$ shows a longitudinal section of a burrow with two openings, and Figure $7 \mathrm{~B}$ the extension under a boulder. Usually, there is a bigger front or main opening where the lobster rests, and a smaller rear opening where it can escape when disturbed. In the typical burrow, a small wall is also found in front of the rear opening. Occasionally, the tunnel connecting the two openings is made somewhat wider in the central part. Tunnel lengths vary with the size of the stones. A few burrows also have a third opening (Fig. $7 \mathrm{C}$ ).

Aquarium experiments demonstrate that a lobster can excavate a complete tunnel under a boulder or stone. The lobsters certainly possess this ability in their natural habitat but many of the tunnel-formed burrows found in nature are definitely constructed where the lobster is assisted by the bottom configuration, etc. (e.g., natural depressions in the soft-bottom material under a boulder). This is still more likely when burrows with three openings are constructed.

In an investigation of a small area off Lysekil on the Skagerrak coast, the ratio between burrows with one opening and burrows with more than one opening was found to be about 2:1 (DyrERN et al. 1967). CовB (1971) recorded the same ratio in a study of the American lobster. However, later investigations along the whole Swedish coast revealed that excavated burrows with more than one opening are scarcer and that the above-mentioned ratio is more like $4: 1$ or 5:1. Nevertheless, tunnel-formed lobster burrows are a common feature.

\section{OTHER KINDS OF BURROW}

The descriptions above refer to burrows of type B:3 in Table 1 . Crevices in solid rocks containing shellsand (type $A: 4$ ) are rather common as shelters and excavated if necessary (Fig. 8). Cavities in big mounds of stones are often inhabited. When taking over such a cavity, a lobster can improve the chamber by pushing away smaller stones and smoothing out the soft-bottom material (Fig, $9 \mathrm{~A}$ ).

Occasionally, lobsters in Swedish waters are observed digging saucer-like depressions in muddy bottom far from rocks, boulders and stones (type $\mathrm{C}: 2$ ). In aquarium experiments, lobsters kept in tanks with a muddy bottom dug hollows in the corners or even tunnels through the mud (Fig. 9 B). These tunnels showed great similarity to those made by the related Norway lobster Nephrops norvegicus (DYBERN \& HøISAETER 1965 ) and the manner of digging was mainly the same (DYBERN 1965, Rice \& CHAPMAN 1971).

Elsewhere along European coasts, lobsters have been reported to construct 
different forms of burrows in muddy bottom material without using rocks or stones as part of the shelter. EHrenbaum (1896) said that during the cold part of the year lobsters around Helgoland may dig down into shallow soft bottom, and Havinga (1938) mentioned that lobster specimens have been found down in soft-bottom material along the shores of the Osterschelde area. McLeEse \& WIIDER (1964), THOMAs (1968) and Совв (1971) report burrows constructed by the American lobster in the mud of soft bottoms. MCKAY (1926) and Совв (1971) mention that small American lobsters were observed to make burrows with one or two openings upon a plain mud bottom.

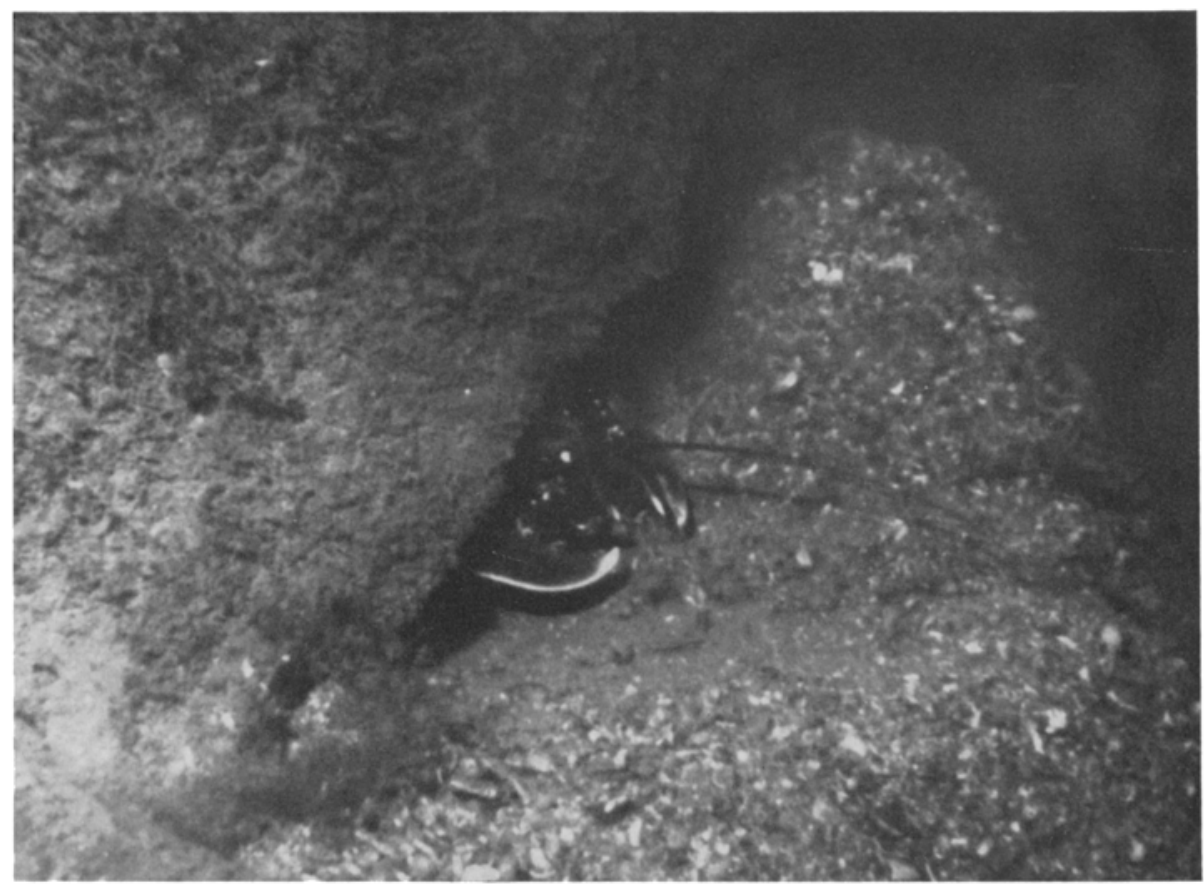

Fig. 8: Lobster burrow in a crevice on a steeply sloping rodk wall. Depth $18 \mathrm{~m}$. (Photo: B. I. DYBERN)

\section{THE BURROWING BEHAVIOUR OF THE LOBSTER}

When a lobster is released by a diver on to a bottom like that in Figure 1 (or in an aquarium tank with a similar bottom) it generally swims backwards into the nearest hole. If no suitable holes are available and the lobster is not disturbed, it begins to aquaint itself with the environment by walking slowly around. If it finds an appropriate place, preferably an overhanging boulder or big stone on sand or shellsand, it may start making a burrow.

The excavating of burrows has mainly been studied in aquaria but all phases described have been confirmed by in situ studies. The lobster generally begins by 
loosening the bottom material with the walking legs. The loosened material is removed by shuffling it off in a "basket" made primarily by the third pair of maxillipeds and the first pair of walking legs (the second pair is also often used) (Fig. $10 \mathrm{~A}$ ). In this manner, the lobster starts to form a depression under the stone ledge, and then penetrates deeper and deeper inwards. The excavated material becomes the wall. Small stones and shells are removed routinely but sometimes the

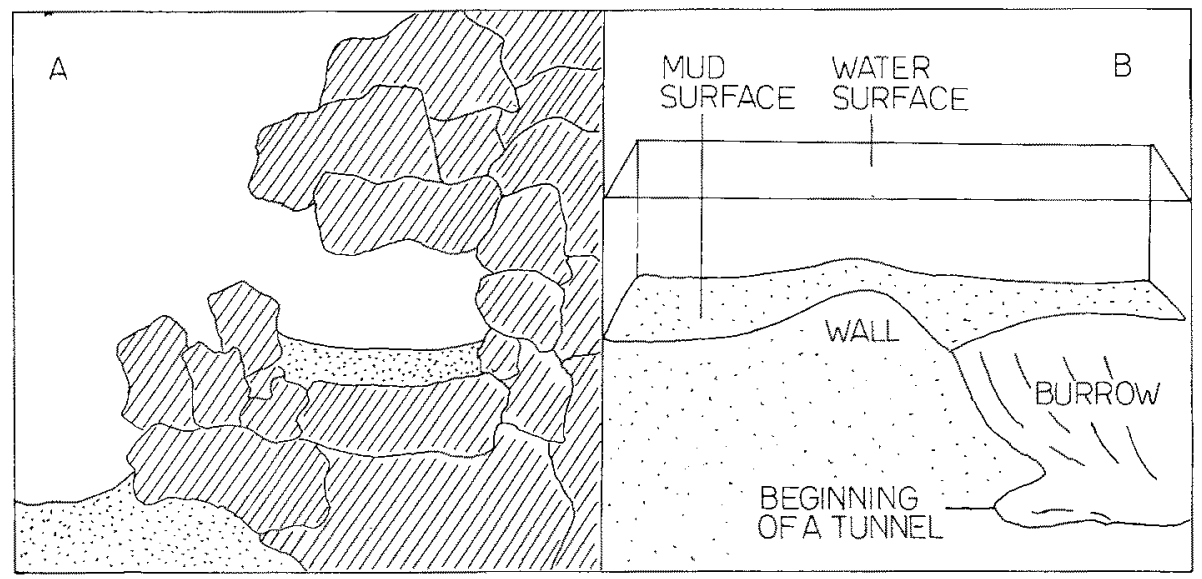

Fig. 9: Lobster burrows. A Cavity among stones. The soft-bottom material was distinctly smoothed out. The diver first saw the lobster resting against the entrance stone. Disturbed, the lobster disappeared among the stones at the rear of the cavity. $B$ Burrow in mud dug in the corner of an aquarium tank (length $2 \mathrm{~m}$ ). The sketch also shows the first stage of a tunnel which was completed later

lobster sweeps away bigger objects with the big claws, seemingly more or less at random. It often turns towards the inner part of the burrow to loosen material with rather clumsy movements of the big claws (Fig. $10 \mathrm{~B}$ ). At the same time it may amass bottom material under the body by using its walking legs. The pile of sand or shellsand is then usually moved away by the "basket-shuffling " method. Sometimes, however, the lobster may lift its abdomen to whisk away lighter material by rapid movements of the pleopods (Fig. $10 \mathrm{C}$ ). Such pleopod fanning is rather common at times when the burrow is more or less completed and, still more, when it is excavated in a muddy bottom.

The big claws are used as described above but not for true digging. The telson serves mainly as a support.

Tunnels under stones (Fig. 7) often seem to be made more or less unintentionally; viz., when a burrow has penetrated so deeply that a breakthrough occurs at the inner end. The lobster in any case improves the rear opening by shuffling out bottom material through it and thus a small rear wall is formed (Fig. $7 \mathrm{~A}$ ). When dwelling in a tunnel, the lobster is well aware of the rear opening and escapes through it when attacked at the front opening.

Although a stereotypic behaviour, basically, the burrowing behaviour may be modified by the kind of bottom substrate and form of stones, etc. As mentioned, 
lobsters often take possession of empty burrows made by other specimens or crabs. Frequently, the burrows are then improved according to the instinct of the new inhabitants.

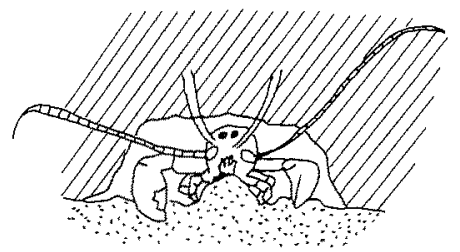

A

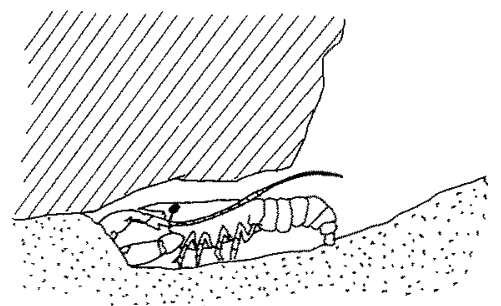

B

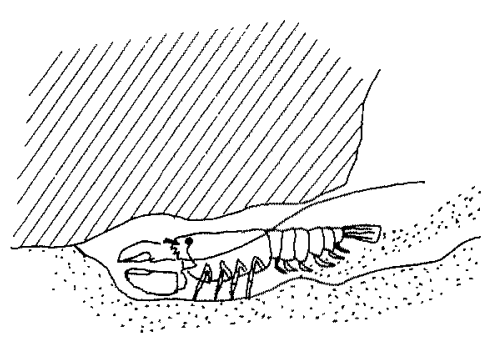

C

Fig. 10: Three burrowing-behavior patterns. A Lobster shuffling pile of soft-bottom material from burrow to outside wall. $B$ Big claws loosen material in front while walking legs loosen naterial under the body. C Pleopod fanning. Patterns $B$ and $C$ are frequent when lobster constructs burrows and tunnels in muddy bottom (as in Fig. $9 \mathrm{~B}$ )

CoBB (1971) has described the burrowing behaviour of the American lobster, and there seems to be no great difference between its behaviour and that of the European lobster. As intimated, the digging behaviour is also similar to that of the Norway lobster Nephrops norvegicus, which mainly constructs tunnels in bottom mud, but which is also able to make burrows under stones (DYBERN 1965).

\section{SUMMARY}

1. The typical habitat of the European lobster (Homarus vulgaris) is rocky or sof bottom with crevices, boulders and stones.

2. At the Swedish west coast it favours a bottom with stones and boulders on sand or shellsand, where it can dig burrows in the soft bottom material under the stones or boulders.

3. Such burrows have one, or more than one, opening; in the latter case usually two. A relationship between the size of a lobster and its burrow is often, but not always, noted. The lengths of tunnel-formed burrows, for instance, vary with the size of the overlying stones.

4. External factors more or less important in the choice of the site of a burrow are, 
for example, the composition of the bottom material, the occurrence of slightly overhanging edges of stones or rocks, an outwards-downwards sloping bottom, highest possible values of salinity and temperature, and a sparse algal vegetation or no vegetation at all. Lobsters tend to be absent from polluted areas where the sedimentation rate of organic particles and the turbidity of the water are high.

5. Besides being shelters, the burrows also serve as look-outs.

6. Burrows may be dug in soft-bottom material in rocky crevices or in flat mud bottoms.

7. The burrowing behaviour is characterized by three main patterns: (a) loosening of the bottom material with the walking legs and sometimes with the big claws, (b) shuffling off of piles of soft bottom material in a "basket" formed by the 3 rd pair of maxillipeds and one or two pairs of walking legs, and (c) fanning backwards with the pleopods.

8. Small lobsters behave like adults.

9. The burrowing behaviour is very similar to that of the American lobster and resembles that of Nepbrops norvegicus.

\section{LITERATURE CITED}

Alvarez, R. Z., 1946. Crustacéos Decapódos Mediterráneos. Instituto Espanol de Estudios Mediterráneos. Publnes Biol. mediterr. 2, 1-181.

AppextöF, A., 1899. Mittheilungen aus der Lebensweise des Hummers. Mitt. dt. SeefischVer. $15,99$.

- 1909. Undersøkelser over hummeren. Årsberetn. Norg. Fisk. 1909, 3-153.

Bö̈тrUS, J., 1954. Traek af hummerens liv. Naturen 1954, 430-440.

Совв, J. S., 1971. The shelter-related behavior of the lobster, Homarus americanus. Ecology 52, 108-115.

Dannevig, A., 1927. Bidrag til hummerens naturhistorie. Nytt Mag. Naturvid. 65, 83-109.

- 1936. Hummer og hummerkultur. FiskDir. Skr. (Havundersøkelser) 4 (12), 1-60.

DANNEvig, G., 1962. Hummeren og hummerfisket. Noen aktuelle problemer. Fauna, Oslo 15, 197-204.

Dybern, B. I., 1965. On the burrowing behaviour of Nephrops norvegicus. Coun. Meet. int. Coun. Explor. Sea ( $=$ C. M.-I.C.E.S.) 145.

- \& Høisaeter, T., 1965. The burrows of Nepbrops norvegicus (L.). Sarsia 21, 49-55.

- Jacobsson, L. \& Hallbäck, H., 1967. On the habitat behaviour of the lobster (Homarus vulgaris) in Swedish waters. Meddn. HavsfiskLab. Lysekil 36, 1-7.

Ehrenbaum, E., 1896. Der Hummer. Eine Zusammenstellung der Resultate neuerer Untersuchungen. Mitt. dt. SeefischVer. 12, 207-213.

Havinga, B., 1938. Krebse und Weichtiere. Handb. Seefisch. Nordeur. 3 (2), 1-147.

- 1951. Shellfish in the Netherlands. - Rapp. P.-v. Réun. Cons. perm. int. Explor. Mer. 128, $64-68$.

Herrtck, F. H., 1895. The American lobster - a study of its habits and development. Bull. U.S. Fish Commn 15, 1-252.

Höglund, H., 1964. De matnyttiga kräftjuren. Hummern, Homarus gammarus (LiNné). In: Fiskar och Fiske i Norden. Ed. by K. A. ANDERsson. Bokförlaget Natur och Kultur, Stockholm 1, 226-235.

Korringa, P., 1957. Risks involved in lobster storage. Coun. Meet. int. Coun. Explor. Sea $(=$ C.M.I.C.E.S.)

McKay, D. A., 1926. Post larval lobsters. Science, N. Y., 64, 530. 
McLeese, D. M. \& WILDER, D. G., 1964. Lobster storage and shipment. Bull. Fish. Res. Bd Can. 147, 1-69.

Palohermo, J. E., 1963. Estimation of catchabilities and population sizes of lobsters. J. Fish. Res. Bd Can. 20, 59-88.

Poulser, E. M., 1927. Om Hummeren og Hummerfiskeriet i de danske farvande. Skr. Danm. Fisk. - og Havunders. 10, 1-41.

Rice, A. L. \& Chapman, C. J., 1971. Observations on the burrows and burrowing behaviour of two mud-dwelling decapod crustaceans, Nephrops norvegicus and Goneplax rhomboides. Mar, Biol. 10, 330-342.

Scarratt, D. J., 1968. An artificial reef for lobsters (Homarus americanus). J. Fish. Res. Bd Can. 25, 2683-2690.

Simpson, A. C., 1958. The lobster fishery of Wales. Ministry of Agriculture, Fisheries and Food. Fisher Invest. (Ser. 2) 22 (3), 1-33.

Stephensen, K., 1910. Storkrebs. I. Skjoldkrebs. Danm. Fauna 9, 1-193.

Templeman, W., 1937. The lobster and lobster fishery. Can. Fisherm. 1937 (April), 14-15.

THomas, H. J., 1958. Lobster and crab fisheries in Scotland. Mar. Res. 1958 (8), 1-107.

Thomas, M. L. H., 1968. Overwintering of American lobsters, Homarus americanus, in burrows in Bideford River, Prince Edward Island. J. Fish. Res. Bd Can. 25, 2725-2727.

Vatova, A., 1928. Compendio della Flora e Fauna del Mare Adriatico presso Rovigno. R. Inst. biol. mar. Royigno 14, 1-613.

Author's address: Dr. B. I. DYBeRN

Havsfiskelaboratoriet

S-45300 Lysekil

Sweden 